\section{Plant Morphology and Yield of Paprika Pepper in Response to Method of Stand Establishment}

\author{
James R. Cooksey ${ }^{1}$, Brian A. Kahn ${ }^{2}$, and James E. Motes ${ }^{3}$ \\ Department of Horticulture and Landscape Architecture, Oklahoma State \\ University, Stillwater, OK 74078-0511
}

Additional index words. Capsicum annuum, mechanical harvest, plant architecture, primed seed, transplanting

\begin{abstract}
Nontreated seed, primed seed, and transplants were compared for effects on stand establishment, plant morphology, and yield of paprika pepper (Capsicum annuum L.). Nontreated seed was satisfactory for stand establishment, although primed seed had the potential to provide greater initial stands. When populations were made equal by thinning, there were few differences in stem and leaf dry weight, fruit yield, or plant morphology attributed to seed treatment. Generally, morphology of plants established by direct seeding was favorable for mechanical harvest. Using transplants did not result in higher marketable fruit yields than direct seeding in 2 of 3 years. When compared to plants established by direct seeding, three trends were consistent across all 3 years for plants established by transplanting: 1) they were more massive, 2) they had larger vertical fruiting planes, and 3) they had more branches. These traits increase the difficulty of mechanical harvest and create the potential for more leaves and stems (trash) in the harvested product. Thus, transplanting is not recommended for stand establishment of paprika pepper intended for mechanical harvest.
\end{abstract}

Most of the published studies on stand establishment for Capsicum annuum involve bell rather than paprika pepper. Although there are some similarities, bell pepper production involves different cultural systems than paprika production. In particular, bell peppers ordinarily are harvested by hand, but mechanical harvesting is considered essential to expand production of paprika-type peppers (Bender, 1993; Palevitch, 1978). A prerequisite for mechanical harvesting is the development of cultural practices that facilitate a single, destructive harvest (Palevitch, 1978).

Primed seed and transplants have been used as alternatives to nontreated seed for pepper stand establishment. Primed pepper seed germinates more rapidly than nontreated

Received for publication 4 Apr. 1994. Accepted for publication 6 July 1994. Approved for publication by the Director of the Oklahoma Agricultural Expt. Station. This research was supported under project H-2026, with additional support from Oklahoma Center for the Advancement of Science and Technology grant ARO-087. The information given in this publication is for educational purposes only. Mention of a trademark, proprietary product, or vendor does not constitute a guarantee or warranty of the product, nor does it imply approval or disapproval to the exclusion of other products or vendors that also may be suitable. The cost of publishing this paper was defrayed in part by the payment of page charges. Under postal regulations, this paper therefore must be hereby marked advertisement solely to indicate this fact.

${ }^{1}$ Former Graduate Assistant.

${ }^{2}$ Professor, to whom reprint requests should be addressed.

${ }^{3}$ Professor. seed, although final germination percentages usually are not improved by using primed seed (O'Sullivan and Bouw, 1984; Smith and Cobb, 1991; Sundstrom and Edwards, 1989; Yaklich and Orzolek, 1977). Seedling development and emergence rates also were more rapid with primed pepper seed than with nontreated seed (Bradford et al., 1990; Khan et al., 1992; Rivas et al., 1984; Sundstrom and Edwards, 1989; Yaklich and Orzolek, 1977). Total fruit yields from plants established by transplanting usually are equal to or greater than yields from bell pepper (Ghate et al., 1984; Leskovar and Cantliffe, 1993) and Tabasco pepper (Capsicum frutescens L.) (Sundstrom et al., 1987) plants established by direct seeding.

Some of the first Oklahoma growers of paprika pepper established fields by direct seeding and by transplanting. We observed differences in plant morphology among these fields. Plant morphology may have a significant impact on the efficiency of mechanical pepper harvest (Marshall, 1984). Leskovar and Cantliffe (1993) reported that bell pepper plants established by direct seeding maintained a more balanced root, stem, leaf, and fruit dry-matter partitioning than plants established by transplanting. We did not find other studies relating stand establishment method to pepper plant morphology.

Our objective was to compare nontreated seed, primed seed, and transplants for effects on stand establishment, plant morphology, and yield of paprika pepper.

\section{Materials and Methods}

Field experiments were conducted at the Fort Cobb Research Station, Fort Cobb, Okla., from 1990 to 1992 . The Cobb fine sandy loam (fine-loamy, mixed, thermic, Udic Haplustalf) at Fort Cobb was prepared with a broadcast preplant-incorporated application of (in $\mathrm{kg} \mathrm{ha}^{-1}$ ) $40 \mathrm{~N}-45 \mathrm{P}-112 \mathrm{~K}, 72 \mathrm{~N}-24 \mathrm{P}-46 \mathrm{~K}$, and $50 \mathrm{~N}-$ $56 \mathrm{P}-0 \mathrm{~K}$ in 1990,1991 , and 1992 , respectively, based on soil tests and Oklahoma State Univ. recommendations (Motes, 1993). One topdressing was made each year at first flowering to supply $\mathrm{N}$ at $45 \mathrm{~kg} \cdot \mathrm{ha}^{-1}$. Weeds were controlled with a preplant application of $N, N$ diethyl-2-(1-naphthaleneyloxy)-propionamide (napropamide) at $1.7 \mathrm{~kg} \cdot \mathrm{ha}^{-1}$ and cultivation. Sprinkler irrigation was provided based on subjective visual and tactile soil observations.

Nontreated or commercially primed seed (Kamterter, Lincoln, Neb.) of 'Oklahoma Paprika 50', an advanced breeding line with an upright growth habit, was used for direct seeding in 1990 and 1991; only nontreated seed was used in 1992. Field spacing was $0.9 \mathrm{~m}$ between rows and $0.1 \mathrm{~m}$ between plants within rows. Plots were seeded on 12 Apr. 1990, 15 Apr. 1991, and 8 Apr. 1992 at 2 to $3 \mathrm{~kg} \cdot \mathrm{ha}^{-1}$. In 1990, direct-seeded plots were not thinned because stands approached the desired density. Plants were counted in direct-seeded rows on 21 May 1991, followed by thinning on 10 June. In 1992, direct-seeded rows were thinned on 12 June.

Nontreated seed was sown in a greenhouse on 6 Mar. 1990, 4 Mar. 1991, and 12 Mar. 1992 for transplant production. Transplants were grown in peat-lite mix in flats with inverted pyramid cells (volume per cell, $\approx 18 \mathrm{~cm}^{3}$; Speedling, Sun City, Fla.) in 1990 or in bulk benches (1991 and 1992). Transplants were set in the field on 8 May 1990, 24 Apr. 1991, and 24 Apr. 1992. All plots were $9 \mathrm{~m}$ long. Plots were three (1990) or four (1991 and 1992) rows wide, with the center row(s) used for data collection.

To simulate grower practices, a single destructive harvest was made after a frost in each year. Dates of harvest were 20 Nov. 1990, 9 Nov. 1991, and 13 Nov. 1992. Three procedures were performed just before harvest. First, lodged plants (root, stem, or branch lodging) were counted in 4- to 6-m row sections. Next, force to uproot a plant was measured on three or four plants per plot using a cable puller, milk scale, and a lever based on a fulcrum. Then, three plants per plot were sampled for morphology data. Distances were measured from the soil to the first branch, the first fork in the main stem, the highest plant part, the first fruit attachment, and the highest fruit attachment. The number of major branches at the first fork in the main stem and the total number of branches per plant subsequently were determined in the laboratory on sampled plants.

Once preharvest procedures were completed, plants in a 3-m section of each plot were cut by hand at soil level, counted, and placed in burlap sacks. Fruit were removed from the plants in the laboratory. Fruit that were orange, green, bleached, or filled with fungi were classified as culls. Marketable fruit were leathery, partially dried, and deep red. All plant material was dried at $48 \mathrm{C}$ for $\geq 7$ days and weighed. 
Table 1. Response of paprika pepper to method of stand establishment, Fort Cobb, Okla. Dry weights are reported.

\begin{tabular}{|c|c|c|c|c|c|c|c|}
\hline \multirow[b]{2}{*}{$\begin{array}{l}\text { Plant } \\
\text { establishment } \\
\text { method }\end{array}$} & \multirow[b]{2}{*}{$\begin{array}{c}\text { Final } \\
\text { stand } \\
\left(\text { no. } / \mathrm{m}^{2}\right)\end{array}$} & \multirow{2}{*}{$\begin{array}{c}\text { Avg wt } \\
\text { stems + } \\
\text { leaves } \\
\text { (g/plant) }\end{array}$} & \multirow[b]{2}{*}{$\begin{array}{c}\text { Lodged } \\
\text { plants } \\
(\%)\end{array}$} & \multirow{2}{*}{$\begin{array}{l}\text { Force to } \\
\text { uproot a } \\
\text { plant } \\
(\mathrm{N})\end{array}$} & \multicolumn{3}{|c|}{ Harvested fruit } \\
\hline & & & & & $\begin{array}{c}\text { Marketable } \\
\text { wt } \\
\left(\mathrm{g} \cdot \mathrm{m}^{-2}\right)\end{array}$ & $\begin{array}{c}\text { Total } \\
\text { wt } \\
\left(\mathrm{g} \cdot \mathrm{m}^{-2}\right)\end{array}$ & $\begin{array}{c}\% \text { By wt of } \\
\text { total that was } \\
\text { marketable }\end{array}$ \\
\hline & & & 1990 & & & & \\
\hline Nontreated seed & 11 & 11 & 11 & 98 & 93 & 144 & 64 \\
\hline Primed seed & 13 & 9 & 6 & 108 & 87 & 140 & 62 \\
\hline Transplants & 10 & 13 & 24 & 88 & 102 & 156 & 65 \\
\hline \multicolumn{8}{|l|}{ Contrasts } \\
\hline Seed vs. transplants & NS & $* *$ & $* *$ & $* *$ & NS & NS & NS \\
\hline Nontreated vs. primed seed & NS & $*$ & NS & NS & NS & NS & NS \\
\hline & & & 1991 & & & & \\
\hline Nontreated seed & 10 & 10 & 16 & 78 & 17 & 55 & 32 \\
\hline Primed seed & 10 & 9 & 12 & 98 & 16 & 49 & 34 \\
\hline Transplants & 11 & 16 & 14 & 98 & 61 & 124 & 48 \\
\hline \multicolumn{8}{|l|}{ Contrasts } \\
\hline Seed vs. transplants & $*$ & $* *$ & NS & NS & $* *$ & $* *$ & $* *$ \\
\hline Nontreated vs. primed seed & NS & NS & NS & $*$ & NS & NS & NS \\
\hline & & & 1992 & & & & \\
\hline Nontreated seed & 11 & 8 & 10 & 108 & 66 & 89 & 73 \\
\hline Transplants & 11 & 10 & 14 & 118 & 80 & 108 & 73 \\
\hline Main effect & NS & NS & NS & NS & NS & NS & NS \\
\hline
\end{tabular}

Ns, *,*** Nonsignificant or significant at $P \leq 0.05$ or 0.01 , respectively.

The design was a randomized complete block with five (1990) or six (1991 and 1992) replications. We used an analysis of variance to evaluate data and orthogonal contrasts (where appropriate) to compare stand establishment methods.

\section{Results and Discussion}

When referring to our data, the term "direct seeding" represents the average effect of sowing nontreated or primed seed in a given year, in contrast to the effect of transplanting.

Final stands did not differ among treatments in 1990 and 1992 (Table 1). In 1991, primed seed gave denser initial stands than nontreated seed (53 and 40 plants $/ \mathrm{m}^{2}$, respectively, significant at $P \leq 0.05)$. Khan et al. (1992) and Leskovar et al. (1990) reported that primed seed had the potential to produce denser initial stands than nontreated seed. Others have obtained similar (Bradford et al., 1990; O'Sullivan and Bouw, 1984) or more complete (Sundstrom et al., 1987) pepper stand establishment with nontreated than with primed seed. After thinning, stands established by direct seeding usually were similar to those established by transplanting. The exception was in 1991, when occasional dead plants, due to environmental stresses during the growing season, caused final stands in plots established by direct seeding to be thinner (by one plant/ $\mathrm{m}^{2}$ ) than stands in plots established by transplanting. Overall, we found nontreated seed to be satisfactory for stand establishment.

In 2 of 3 years, average stem and leaf dry weights per plant were significantly higher in plants established by transplanting than in plants established by direct seeding (Table 1). This contrasts with a report in Israel by Palevitch (1978) who found that paprika pepper plants established by transplanting were shorter and had less vegetative growth than plants established by direct seeding. Our transplants had several weeks of growth in the greenhouse before stand establishment in the

Table 2. Plant morphology of paprika pepper in response to method of stand establishment, Fort Cobb, Okla. Data are on a per plant basis.

\begin{tabular}{|c|c|c|c|c|c|c|}
\hline \multirow{2}{*}{$\begin{array}{l}\text { Plant } \\
\text { establishment } \\
\text { method } \\
\end{array}$} & \multicolumn{4}{|c|}{$\mathrm{Ht}(\mathrm{cm})$ from soil to } & \multirow{2}{*}{$\begin{array}{c}\text { Vertical } \\
\text { fruiting } \\
\text { plane }(\mathrm{cm})^{z} \\
\end{array}$} & \multirow{2}{*}{$\begin{array}{c}\text { Total } \\
\text { no. } \\
\text { branches } \\
\end{array}$} \\
\hline & $\begin{array}{c}\text { First } \\
\text { branch }\end{array}$ & $\begin{array}{c}\text { Highest } \\
\text { plant part }\end{array}$ & $\begin{array}{c}\text { First fruit } \\
\text { attachment }\end{array}$ & $\begin{array}{c}\text { Highest fruit } \\
\text { attachment }\end{array}$ & & \\
\hline \multicolumn{7}{|c|}{1990} \\
\hline Nontreated seed & 12 & 58 & 25 & 51 & 26 & 43 \\
\hline Primed seed & 10 & 55 & 22 & 47 & 25 & 51 \\
\hline Transplants & 6 & 58 & 22 & 55 & 33 & 66 \\
\hline \multicolumn{7}{|l|}{ Contrasts $^{y}$} \\
\hline Seed vs. transplants & $*$ & NS & NS & $*$ & NS & $* *$ \\
\hline \multicolumn{7}{|c|}{1991} \\
\hline Nontreated seed & 6 & 42 & 16 & 37 & 21 & 84 \\
\hline Primed seed & 3 & 38 & 12 & 33 & 21 & 91 \\
\hline Transplants & 5 & 50 & 14 & 46 & 32 & 107 \\
\hline \multicolumn{7}{|l|}{ Contrasts $^{y}$} \\
\hline Seed vs. transplants & NS & $*$ & NS & $* *$ & ** & NS \\
\hline \multicolumn{7}{|c|}{1992} \\
\hline Nontreated seed & 9 & 42 & 19 & 33 & 14 & 62 \\
\hline Transplants & 4 & 41 & 14 & 35 & 21 & 88 \\
\hline Main effect & NS & NS & $*$ & NS & NS & $*$ \\
\hline
\end{tabular}

${ }^{2}$ Average vertical distance from first fruit attachment to highest fruit attachment

"All contrasts of "Nontreated vs. primed seed" for variables in this table were not significant at $P \leq 0.05$. Ns, *,**Nonsignificant or significant at $P \leq 0.05$ or 0.01 , respectively.

field, which might have resulted in large plants (Ghate et al., 1984). However, transplanting produced taller plants than direct seeding only in 1991 (Table 2). Furthermore, plants established by transplanting had more branches than plants established by direct seeding. Apparently, growth patterns of plants established by transplanting differed from those of plants established by direct seeding, as proposed by Leskovar et al. (1990) and Leskovar and Cantliffe (1993).

Stand establishment method affected lodging only in 1990 (Table 1), when plants established by transplanting lodged more than plants established by direct seeding. In 1990, the 9week-old transplants may have been more susceptible to stem lodging than the younger transplants used in 1991 and 1992. Setting transplants in the field had been delayed by inclement weather in 1990. Also, a relatively low force was required to uproot transplanted plants in 1990. Marshall (1984) reported that transplanted pepper plants were more likely to be uprooted by a mechanical harvester than plants established by direct seeding. Plants established by primed seed tended to require more force to uproot than plants established by nontreated seed, but differences were significant only in 1991. Leskovar et al. (1990) found that plants established by primed seed and plants established by nontreated seed differed in root growth rate at soil depths of 10 to $20 \mathrm{~cm}$.

Only in 1991 did transplanting result in significantly higher marketable weights and total weights of harvested fruit than direct seeding (Table 1), probably due to a hail storm on 29 Aug. 1991 in which blooms and fruit were more easily damaged under the smaller, less dense canopies produced by plants in the direct-seeded plots. The hail damage was evi- 
dent, especially in the decreased percentage of marketable fruit in 1991 compared to 1990 and 1992, when there was no hail damage. The plants responded to this late-summer hail damage with a flush of new blooms, resulting in many immature green fruit at harvest.

Method of stand establishment had few consistent effects on distances from the soil to the first branch, highest plant part, and first fruit attachment (Table 2). However, in 1990 and 1991, there was more distance from the soil to the highest fruit attachment in plants established by transplanting than in plants established by direct seeding. Overall, plants established by transplanting tended to have the largest vertical fruiting planes, showing that the fruit was dispersed and not concentrated in the canopy. Whether or not fruit dispersion would be advantageous for mechanical harvest may depend on the specific machine used. Marshall (1984) stated that a concentrated set of fruit low on the plant was undesirable for pepper harvest with a helix-type machine. However, a large vertical fruiting plane could increase the possibility that a stripper-type harvester would miss some fruit, especially if the distance from the soil to the first fruit attachment was $<15 \mathrm{~cm}$ (Somos, 1984).

The distance from the soil to the first fork in the main stem and the number of major branches at this point were not significantly $(P$ $\leq 0.05$ ) affected by method of stand establishment in any year (data not presented).

Transplanting resulted in $>20$ more branches per plant than direct seeding when averaged across all 3 years (Table 2). A large number of branches entrap fruit, making mechanical harvest more difficult (Marshall, 1984), and may increase the amount of leaves and stems (trash) in the harvested product (Wolf and Alper, 1984).

When populations were equalized naturally (1990) or by thinning (1991), there were few differences in stem and leaf dry weight, fruit yield, or plant morphology attributable to using nontreated vs. primed seed. This result agrees with the data of Leskovar and Cantliffe (1993) and Sundstrom et al. (1987). In our study, morphology of plants established by direct seeding generally was favorable for mechanical harvest.

Transplanting did not result in higher marketable fruit yields than direct seeding, except when hail damaged the plants (1991). Contrasts of direct seeding vs. transplanting for plant morphology variables were not always significant at $P \leq 0.05$ due to plot-to-plot variability. However, when compared to plants established by direct seeding, three trends were consistent across all 3 years for plants established by transplanting: 1 ) they were more massive, 2) they had larger vertical fruiting planes, and 3) they had more branches. These traits are associated with increased difficulty in mechanical harvesting (Marshall, 1984; Somos, 1984). Also, production expenses would be lower with direct seeding than with transplanting due to lower costs for labor and planting materials (Somos, 1984). Therefore, we would not recommend transplanting for stand establishment of paprika pepper intended for mechanical harvest.

\section{Literature Cited}

Bender, D.A. 1993. Pepper production and harvesting research for the High Plains. In: B. Villalon (ed.). Proc. 9th Biennial Texas Pepper Conf., Weslaco, Texas.

Bradford, K.J., J.J. Steiner, and S.E. Trawatha. 1990. Seed priming influence on germination and emergence of pepper seed lots. Crop Sci. 30:718-721.

Ghate, S.R., S.C. Phatak, and K.M. Batal. 1984. Pepper yields from fluid drilling with additives and transplanting. HortScience 19:281-283.

Khan, A.A., J.D. Maguire, G.S. Abawi, and S. Ilyas. 1992. Matriconditioning of vegetable seeds to improve stand establishment in early field plantings. J. Amer. Soc. Hort. Sci. 117:41-47.
Leskovar, D.I. and D.J. Cantliffe. 1993. Comparison of plant establishment method, transplant, or direct seeding on growth and yield of bell pepper. J. Amer. Soc. Hort. Sci. 118:17-22.

Leskovar, D.I., D.J. Cantliffe, and P.J. Stoffella. 1990. Root growth and root-shoot interaction in transplants and direct seeded pepper plants. Environ. Expt. Bot. 30:349-354.

Marshall, D.E. 1984. Horticultural requirements for mechanical pepper harvesting, p. 389-396. In: Amer. Soc. of Agr. Eng. (ASAE). Proc. Intl. Symp. on Fruit, Nut, and Vegetable Harvesting Mechanization, Bet Dagan, Israel, 5-12 Oct. 1983. ASAE Publ. 5-84.

Motes, J.E. 1993. Paprika machine harvest production suggestions. Coop. Ext. Serv., Okla. State Univ., Stillwater.

O'Sullivan, J. and W.J. Bouw. 1984. Pepper seed treatment for low-temperature germination. Can. J. Plant Sci. 64:387-393.

Palevitch, D. 1978. Cultural practices and cultivars for once-over harvested sweet paprika. Acta Hort. 73:255-262.

Rivas, M., F.J. Sundstrom, and R.L. Edwards. 1984. Germination and crop development of hot pepper after seed priming. HortScience 19:279281.

Smith, P.T. and B.G. Cobb. 1991. Accelerated germination of pepper seed by priming with salt solutions and water. HortScience 26:417-419.

Somos, A. 1984. The paprika. Akadémiai Kiadó, Budapest, Hungary.

Sundstrom, F.J. and R.L. Edwards. 1989. Pepper seed respiration, germination, and seedling development following seed priming. HortScience 24:343-345.

Sundstrom, F.J., R.B. Reader, and R.L. Edwards. 1987. Effect of seed treatment and planting method on Tabasco pepper. J. Amer. Soc. Hort. Sci. 112:641-644.

Wolf, I. and Y. Alper. 1984. Mechanization of paprika harvest, p. 265-275. In: Amer. Soc. of Agr. Eng. (ASAE). Proc. Intl. Symp. on Fruit, Nut, and Vegetable Harvesting Mechanization, Bet Dagan, Israel, 5-12 Oct. 1983. ASAE Publ. 5-84.

Yaklich, R.W. and M.D. Orzolek. 1977. Effect of polyethylene glycol-6000 on pepper seed. HortScience 12:263-264. 